\title{
KUALITAS LABA: INVESTMENT OPPORTUNITY SET DAN KOMITE AUDIT
}

\author{
KIXI OKTAPIANI, ENDANG RUHIYAT \\ Universitas Pamulang, Tangerang Selatan, Indonesia \\ *Email: holienroe@yahoo.co.id
}

\begin{abstract}
This study aims to test and empirically prove the Effect of Investment Opportunity Set and Audit Committee on Profit Quality. The locus of this research is the Property and Real Estate companies listed on the Indonesia Stock Exchange in 2014-2017 consisting of 61 companies. Samples were taken using a purposive sampling technique that produced a sample of 30 companies with observations over 4 (four) years, so that the total observation data was 120 audited financial statements. The data analysis method uses descriptive statistical analysis and multiple linear regression analysis, and hypothesis testing with a significance level of 5\%. The test equipment used was the SPSS version 22 program. Based on the results of the hypothesis test, the investment opportunity set results do not affect earnings quality and the audit committee has a significant effect on earnings quality, while simultaneously shows that investment opportunity set and audit committee have a significant effect on earnings quality.
\end{abstract}

Keywords: Investment Opportunity Set, Audit Committee, Profit Quality

\section{PENDAHULUAN}

\section{Latar Belakang}

Perusahaan menyediakan berbagai macam informasi kepada pihak internal dan eksternal. Salah satu informasi yang tersedia adalah laporan keuangan perusahaan. Laporan keuangan perusahaan merupakan media informasi yang mencerminkan kondisi perusahaan sebagai dasar pengambilan keputusan bagi para pengguna informasi, seperti pihak manajemen, pemilik perusahaan, investor, kreditur, maupun pemerintah. Bagian informasi penting yang terkandung dalam laporan keuangan tersebut adalah informasi laba perusahaan (Nurhanifah dan Jaya 2014).

Informasi laba perusahaan yang dipublikasikan harus menggambarkan kondisi perusahaan yang sebenarnya agar tidak menyesatkan pengguna laporan keuangan dalam mengambil keputusan. Laba yang tidak menyajikan fakta yang sebenarnya tentang kondisi ekonomi perusahaan dapat diragukan kualitasnya 
Jurnal Ilmiah Akuntansi Universitas Pamulang - Vol. 7, No. 2, Juli 2019 - Oktapiani \& Ruhiyat

(Hadiprajitno, 2012). Laba dari perusahaan yang diragukan kualitasnya dapat menyebabkan kesalahan pengambilan keputusan bagi pihak yang memerlukan informasi laba perusahaan baik investor maupun kreditur. Laba yang ditunjukkan dalam laporan keuangan merupakan salah satu faktor pertimbangan investor untuk berinvestasi ke dalam suatu perusahaan (Fahlevi, 2016).

Investor yang rasional biasanya sangat mempertimbangkan risiko dalam berinvestasi terkait dalam hal kualitas laba suatu perusahaan. Untuk itu investor cenderung akan memilih perusahaan yang memiliki prospek untuk tumbuh yang cukup tinggi di masa depan. Salah satu perusahaan yang memiliki prospek bagus dimasa depan adalah perusahaan sektor property dan real estate. Perusahaan sektor property dan real estate adalah perusahaan yang bisnisnya dikenal memiliki karakteristik cepat berubah (volatile) persaingan yang ketat persisten dan kompleks. Kenaikan harga properti disebabkan karena harga tanah yang cenderung naik dan supply tanah bersifat bertambah besar seiring dengan pertambahan jumlah penduduk serta bertambahnya kebutuhan manusia akan tempat tinggal, perkantoran, pusat pembelanjaan, taman hiburan dan lain-lain. Selayaknya apabila perusahaan pengembang mendapatkan keuntungan yang besar dari kenaikan harga property tersebut dan dengan keuntungan yang diperolehnya maka perusahaan pengembang dapat memperbaiki kinerja keuangannya yang pada akhirnya akan dapat menaikkan harga saham perusahaan tersebut (Setianingsih, 2016).

Usaha property dan real estate memerlukan modal yang sangat besar dan tepat, salah satu modal terbesar yang diperoleh perusahaan yaitu dari investor atau pemegang saham melalui penanaman investasi. Dalam era globalisasi, modal terbesar diperoleh melalui pasar modal. Dalam pengambilan keputusan investasi di pasar modal, investor mempertimbangkan banyak hal berdasarkan informasi perusahaan. Salah satu sumber informasi yang paling banyak diperhatikan oleh investor adalah laporan laba rugi komprehensif, karena terdapat informasi mengenai laba yang dicapai oleh perusahaan dalam periode tertentu (Sufiyati, 2015).

Informasi laba yang mengandung gangguan persepsi menyebabkan informasi laba tersebut menjadi menyesatkan para pemangku kepentingan dan tidak berkualitas. Oleh karena itu, kualitas laba merupakan ukuran kebenaran informasi laba dalam laporan keuangan.

Salah satu faktor yang memengaruhi kualitas laba adalah Investment Opportunity Set (IOS). IOS merupakan kesempatan perusahaan untuk tumbuh. IOS dijadikan sebagai dasar untuk menentukan klasifikasi pertumbuhan perusahaan di masa depan. Bagi perusahaan yang memiliki set kesempatan investasi tinggi senantiasa melakukan ekspansi dalam strategi bisnisnya, maka akan semakin membutuhkan dana eksternal. Perusahaan yang memiliki IOS tinggi memiliki peluang pertumbuhan yang tinggi yang akan mempengaruhi perubahan tingkat laba dan menentukan kualitas informasi laba (Oktarya dkk, 2014).

Faktor berikutnya yang memengaruhi kualitas laba adalah komite audit. Komite audit menurut Komite Nasional Kebijakan Governance (2006) yaitu sekelompok orang yang dipilih oleh kelompok yang lebih besar untuk mengerjakan pekerjaan tertentu atau untuk melakukan tugas-tugas khusus atau 
Jurnal Ilmiah Akuntansi Universitas Pamulang - Vol. 7, No. 2, Juli 2019 - Oktapiani \& Ruhiyat

sejumlah anggota dewan komisaris perusahaan klien yang bertanggungjawab untuk membantu auditor dalam mempertahankan independensinya dari manajemen.

\section{LANDASAN TEORI}

\section{Teori Sinyal (Signaling Theory)}

Spence (1973) mendefiniskan sinyal sebagai kegiatan individu dalam pasar yang secara sengaja atau tidak sengaja mengubah keyakinan dengan menyampaikan informasi kepada individu lain di pasar. Hal ini penting bahwa sinyal yang tepat dapat menyampaikan informasi yang diperlukan yang terkadang tidak bisa diamati. Pengumuman dikatakan mengandung informasi jika dapat memancing reaksi pasar, yaitu perubahan harga saham. Informasi tersebut merupakan sinyal positif, apabila informasi tersebut memberikan dampak positif berupa kenaikan harga saham. Namun apabila informasi tersebut memberikan dampak negatif, maka informasi tersebut dikatakan sinyal negatif.

Informasi laba yang dilaporkan merupakan sinyal mengenai laba di masa yang akan datang, jika informasi laba tersebut relevan bagi para pelaku pasar modal, maka informasi akan digunakan untuk menganalisis dan menginterpretasikan nilai saham perusahaan yang bersangkutan sehingga akan terjadi respon pasar berupa perubahan harga saham perusahaan yang bersangkutan ke harga ekuilibrium yang baru. Harga ekuilibrium ini akan bertahan sampai ada informasi baru lainnya yang akan merubah harga saham kembali ke harga ekuilibrium yang baru (Wahyuningsih, 2013).

Keputusan investor dalam berinvestasi dipengaruhi oleh kualitas informasi yang diungkapkan perusahaan dalam laporan keuangan. Laba akuntansi merupakan salah satu sumber informasi dalam keuangan mengenai kondisi perusahaan dan prospek perusahaan dimasa mendatang yang dapat dilihat dari investment opportunity set (IOS) (Jaya, 2014). IOS yang tinggi cenderung dinilai positif oleh investor karena lebih memiliki prospek keuntungan di masa yang akan datang. Ketika perusahaan memiliki IOS yang tinggi, maka nilai perusahaan akan meningkat karena lebih banyak investor yang tertarik untuk berinvestasi dengan harapan memperoleh return yang lebih besar dimasa yang akan datang. Maka dengan adanya sinyal yang dilakukan perusahaan berupa publikasi informasi laba \& kondisi perusahaan, akan mendapatkan respon dari reaksi pasar yang beragam dan berguna juga bagi kepentingan perusahaan dalam memenuhi modal dalam usahanya.

\section{Teori Keagenan (Agency Theory)}

Teori keagenan Jensen dan Meckling (1976) menyatakan bahwa antara manajemen dan pemilik mempunyai kepentingan yang berbeda. Konflik keagenan menyebabkan terjadinya sifat manajemen yang melaporkan laba secara oportunis untuk memaksimalkan kepentingan pribadinya. Apabila ini terjadi, maka akibatnya adalah rendahnya kualitas laba yang dihasilkan. Rendahnya kualitas laba dapat mengakibatkan para penggunanya membuat kesalahan dalam 
Jurnal Ilmiah Akuntansi Universitas Pamulang - Vol. 7, No. 2, Juli 2019 - Oktapiani \& Ruhiyat

pengambilan keputusan. Laba yang tidak menunjukkan informasi kinerja manajemen yang sebenarnya akan membuat pihak pengguna laporan menjadi tersesat (Kurniawan, 2016).

Teori ini menjelaskan bahwa setiap individu semata-mata termotivasi oleh kepentingan dirinya sendiri sehingga menimbulkan konflik kepentingan di antara mereka. Demikian juga di antara pemilik (principal) dan manajemen (agent) di perusahaan. Di satu sisi agent memiliki informasi yang lebih banyak dibanding dengan principal sehingga menimbulkan adanya asimetry information. Dalam kondisi asimetri, agent dapat memengaruhi angka-angka akuntansi yang disajikan dalam laporan keuangan dengan cara manipulasi laba. Tindakan agent dengan melaporkan laba secara oportunis yang memaksimumkan kepentingan pribadinya dapat menyebabkan rendahnya kualitas laba (Jaya, 2014).

Dalam memastikan kualitas laba perusahaan yang dilaporkan oleh agent maka diperlukan keberadaan komite audit di dalam perusahaan. Komite audit diharapkan dapat membantu dewan komisaris dalam pelaksanaan tugas yaitu mengawasi proses pelaporan keuangan oleh manajemen. Peran komite audit sangat penting karena memengaruhi kualitas laba perusahaan yang merupakan salah satu informasi penting yang tersedia untuk publik dan dapat digunakan oleh investor untuk menilai perusahaan. Investor sebagai pihak luar perusahaan tidak dapat mengamati secara langsung kualitas sistem informasi perusahaan. Oleh karena itu, persepsi mengenai kinerja komite audit akan mempengaruhi penilaian investor terhadap kualitas laba perusahaan.

\section{Kualitas Laba}

PSAK No. 1 tahun 2012 yang menyatakan dengan memberikan informasi mengenai posisi keuangan, kinerja keuangan, dan arus kas entitas bermanfaat bagi sebagian besar kalangan pengguna laporan dalam pembuatan keputusan ekonomi. Kualitas laba mengakui fakta bahwa dampak ekonomi transaksi yang terjadi akan beragam diantara perusahaan sebagai fungsi dari karakter dasar bisnis mereka, dan secara beragam dirumuskan sebagai tingkat laba yang menunjukkan apakah dampak ekonomi pokoknya lebih baik dalam memperkirakan arus kas atau juga dapat diramalkan.

IAI (2012) dalam PSAK Nomor 1, informasi laba diperlukan untuk menilai perubahan potensi sumber daya ekonomis yang mungkin dapat dikendalikan di masa depan, menghasilkan arus kas dari sumber daya yang ada, dan untuk perumusan pertimbangan tentang efektivitas perusahaan dalam memanfaatkan tambahan sumber daya. Informasi laba yang tersajikan dalam laporan keuangan berguna untuk pemilik saham untuk memprediksi laba dimasa yang akan datang, sedangkan bagi investor berguna untuk pengambilan keputusan keputusan dalam menginvestasikan dananya. Investor membeli saham pada saat mereka yakin bahwa laba dimasa yang akan datang dapat meningkatkan harga saham. Sehingga informasi laba yang dipublikasikan haruslah berkualitas agar tidak merugikan investor. 
Jurnal Ilmiah Akuntansi Universitas Pamulang - Vol. 7, No. 2, Juli 2019 - Oktapiani \& Ruhiyat

\section{Investment Opportunity Set (IOS)}

Keputusan investasi tidak dapat diamati secara langsung oleh pihak luar. Beberapa studi yang dilakukan dalam hubungannya dengan keputusan investsasi anatara lain Myers (1984) yang memperkenalkan IOS. IOS memberi petunjuk yang lebih luas dimana nilai perusahaan tergantung pada pengeluaran perusahaan dimasa yang akan datang. Jadi prospek perusahaan dapat ditaksir dari IOS yang didefinisikan sebagai kombinasi antara aktiva yang dimiliki (assets in place) dan pilihan investasi dimasa akan datang dengan net present value positif.

Menurut Warianto (2013), perusahaan dengan IOS tinggi cenderung dinilai positif oleh investor karena lebih memiliki prospek keuntungan di masa yang akan datang. Ketika perusahaan memiliki IOS yang tinggi, maka nilai perushaan akan meningkat karena lebih banyak investor yang tertarik untuk berinvenstasi dengan harapan memperoleh return yang lebih besar dimasa yang akan datang. Mulanti et al (2007) mengungkapkan perusahaan dengan tingkat IOS tinggi akan memiliki kemampuan menghasilkan laba yang lebih tinggi, sehingga pasar akan memberi respon yang lebih besar terhadap perusahaan yang mempunyai pertumbuhan IOS (Wulansari, 2013). Tingginya respon pasar terhadap laba mengindikasikan bahwa perusahaan memilki kualitas laba yang baik.

IOS merupakan kesempatan perusahaan untuk tumbuh. IOS digunakan sebagai dasar untuk menentukan klasifikasi pertumbuhan di masa depan. Bagi perusahaan yang memiliki set kesempatan investasi tinggi senantiasa melakukan ekspansi dalam strategi bisnisnya, maka akan semakin membutuhkan dana eksternal. Perusahaan yang memiliki set kesempatan investasi atau IOS tinggi memiliki peluang pertumbuhan yang tinggi yang akan memengaruhi perubahan tingkat laba dan menentukan kualitas informasi laba (Nurhanifah, 2014).

\section{Komite Audit}

Peraturan OJK No. 55/POJK.04/2015, mewajibkan perusahaan membentuk Komite Audit dengan struktur keanggotaan sekurang-kurangnya satu orang Komisaris dan sekurang-kurangnya dua orang yang tidak terafiliasi dengan Perusahaan. Komite ini berfungsi untuk membantu Dewan Komisaris untuk melakukan pengawasan atas pelaksanaan fungsi Direksi sesuai dengan prinsip Good Corporate Governance (GCG). Komite audit harus beranggotakan minimal tiga orang independen, salah satunya memiliki keahlian dalam bidang akuntansi. Salah seorang anggota komite audit harus berasal dari komisaris independen yang dan merangkap sebagai ketua komite audit. Tugas komite berhubungan dengan kualitas laporan keuangan, yaitu melakukan penelaahan atas informasi keuangan yang akan dikeluarkan perusahaan seperti laporan keuangan dan informasi keuangan lainya. Peran komite audit sangat penting karena mempengaruhi kualitas laba perusahaan yang merupakan salah satu informasi penting yang tersedia untuk publik dan dapat digunakan investor untuk menilai perusahaan.

Komite audit ini diharapkan bisa mendorong penerapan prinsip prinsip GCG (Independency, transparency, accountability and responsibility, and fairness) pada korporasi yang bersangkutan. Prinsip independensi sangat difokuskan terutama pada terjaganya kualitas pelaporan keuangan perusahaan (Reyhan dan Azlina, 2014). 
Jurnal Ilmiah Akuntansi Universitas Pamulang - Vol. 7, No. 2, Juli 2019 - Oktapiani \& Ruhiyat

\section{Pengembangan Hipotesis}

Teori sinyal Spence (1973) mengungkapkan bagaimana seharusnya perusahaan memberikan sinyal kepada pengguna laporan keuangan seperti pemilik ataupun investor.. Laba akuntansi merupakan salah satu sumber informasi keuangan perusahaan. Hasil penelitian membuktikan bahwa investment opportunity set berpengaruh terhadap kualitas laba (Prasetyawati, 2015 dan Wijaya, 2014). Sedangkan komite audit berpengaruh terhadap kualitas laba (Suryanto, 2016 dan Silvi, 2016).

Berdasarkan peraturan OJK No. 55/POJK.04/2015, mewajibkan perusahaan unutk membentuk Komite Audit. Tugas komite berhubungan dengan kualitas laporan keuangan, yaitu melakukan penelaahan atas informasi keuangan yang akan dikeluarkan perusahaan seperti laporan keuangan dan informasi keuangan lainya. Peran komite audit sangat penting karena mempengaruhi kualitas laba perusahaan yang merupakan salah satu informasi penting yang tersedia untuk publik dan dapat digunakan investor untuk menilai perusahaan.

Berdasarkan teori dan bukti empiris tersebut maka dapat dikembangkan hipotesis sebagai berikut:

$\mathrm{H}_{1}$ : Diduga Investment opportunity set dan Komite Audit berpengaruh positif terhadap kualitas laba.

Teori sinyal Spence (1973) mengungkapkan bagaimana seharusnya perusahaan memberikan sinyal kepada pengguna laporan keuangan seperti pemilik ataupun investor. Keputusan investor dalam berinvestasi dipengaruhi oleh kualitas informasi yang diungkapkan perusahaan dalam laporan keuangan. Laba akuntansi merupakan salah satu sumber informasi keuangan perusahaan. Penelitian yang dilakukan oleh Prasetyawati (2015) dan Wijaya (2014) menghasilkan kesimpulan bahwa investment opportunity set berpengaruh terhadap kualitas laba.

Berdasarkan teori dan bukti empiris tersebut maka dapat dikembangkan hipotesis sebagai berikut:

$\mathrm{H}_{2}$ : Diduga Investment opportunity set berpengaruh positif terhadap kualitas laba

Komite audit bertugas membantu dewan komisaris untuk memonitor proses pelaporan keuangan oleh manajemen unutk meningkatkan kredibiltas laporan keuangan (Bradbury et al. 2004). Tugas komite audit meliputi menelaah kebijakan akuntansi yang diterapkan oleh perusahaan, menilai pengendalian internal, menelaah sistem pelaporan eksternal dan kepatuhan terhadap peraturan (Suryanto, 2016).

Tugas komite audit berhubungan dengan kualitas laporan keuangan, karena komite audit diharapkan dapat membantu dewan komisaris dalam pelaksanaan tugas yaitu mengawasi proses pelaporan keuangan oleh manajemen. Peran komite audit sangat penting karena mempengaruhi kualitas laba perusahaan yang merupakan salah satu informasi penting yang tersedia untuk publik dan dapat digunakan investor dalam menilai perusahaan. Investor sebagai pihak luar perusahaan tidak dapat mengamati secara langsung kualitas sistem informasi perusahaan (Teoh dan Wong, 1993). Oleh karena itu persepsi mengenai kinerja 
Jurnal Ilmiah Akuntansi Universitas Pamulang - Vol. 7, No. 2, Juli 2019 - Oktapiani \& Ruhiyat

komite audit akan memengaruhi penilaian investor terhadap kualitas laba perusahaan.

Anderson et al. (2003) menemukan bahwa karakteristik komite audit (independensi, aktivitas dan ukuran komite audit) mempengaruhi kandungan informasi dari laba yang diukur dengan ERC. Peningkatan independensi dan aktivitas komite audit berpengaruh positif terhadap kandungan informasi dari laba. Penelitian yang dilakukan oleh Suryanto (2016) dan Silvi (2016) menghasilkan kesimpulan bahwa komite audit berpengaruh terhadap kualitas laba. Berdasarkan teori dan bukti empiris tersebut maka dapat dikembangkan hipotesis sebagai berikut:

$\mathrm{H}_{3}$ : Diduga Komite Audit berpengaruh positif terhadap kualitas laba

\section{METODE PENELITIAN}

Penelitian ini menggunakan metode deskriptif dengan pendekatan kuantitatif yang bertujuan untuk membuktikan secara empiris pengaruh IOS dan komite audit terhadap kualitas laba yang diuji dengan model regresi linear berganda menggunakan aplikasi SPSS 22.

Lokus penelitian adalah perusahaan Property dan Real Estate yang listing di Bursa Efek Indonesia. Metode sampel menggunakan teknik purposive sampling. Ada sebanyak 30 (tiga puluh) perusahaan yang memenuhi kriteria. Data dikumpulkan dengan cara dokumentasi yaitu dengan mendownload data laporan keuangan tahun 2014-2017 dari website BEI www.idx.co.id. Dengan demikian data yang diobservasi sebanyak 120 data.

\section{HASIL DAN PEMBAHASAN}

\section{Analisis Statistik Deskriptif}

Tabel 4.1

Hasil Statistik Deskriptif

\begin{tabular}{lccccc}
\hline & $\mathrm{N}$ & Minimum & Maximum & Mean & Std. Deviation \\
\hline \hline Investment & 72 & 0.15 & 6.57 & 1.42 & 1.34 \\
Opportunity Set & 72 & 0.50 & 0.75 & 0.67 & 0.03 \\
Komite Audit & 72 & 0.04 & 1.25 & 0.44 & 0.26 \\
Kualitas Laba & 72 & & & & \\
Valid N (listwise) & & & & \\
\hline
\end{tabular}

Sumber : Output IBM SPSS Statistics 22.0 (diolah 2019)

Penjelasan mengenai statistik deskriptif untuk masing masing variabel adalah sebagai berikut :

1. Jumlah pengamatan untuk variabel investment oppotunity set adalah sebesar 72 pengamatan yang diperoleh dari 27 perusahaan dengan periode 4 tahun 
Jurnal Ilmiah Akuntansi Universitas Pamulang - Vol. 7, No. 2, Juli 2019 - Oktapiani \& Ruhiyat

diketahui memiliki nilai minimum sebesar 0,15 dimiliki oleh PT Suryamas Dutamakmur Tbk pada tahun 2016, nilai maksimum sebesar 6,57 dimiliki oleh PT Metropolitan Kentjana Tbk pada tahun 2016. Dalam tabel 4.3 juga dapat dilihat nilai rata-rata sebesar 1,42 dengan standar deviasinya sebesar 1,37. Dalam hal ini menunjukkan bahwa nilai rata-rata (mean) lebih besar daripada standar deviasi maka dapat dikatakan kualitas data cukup baik.

2. Jumlah pengamatan untuk variabel komite audit yang diukur dengan prosentase anggota komite audit yang berasal dari luar perusahaan terhadap seluruh anggota komite audit adalah sebesar 72 pengamatan yang diperoleh dari 27 perusahaan dengan periode 4 tahun diketahui memiliki nilai minimum sebesar 0,50 dimiliki oleh Perdana Gapuraprima Tbk pada tahun 2014 dan Lippo Cikarang Tbk pada tahun 2017, nilai maksimumnya adalah 0,75 dimiliki oleh PT. Metropolitan Kentjana Tbk pada tahun 2016, nilai rata-rata adalah 0,67 dan standar deviasi sebesar 0,03 . Nilai tersebut memiliki arti bahwa dari 72 data diketahui bahwa rasio yang menunjukkan anggota komite audit yang berasal dari luar perusahaan dimiliki perusahaan minimum sebesar $0,67 \%$ dan maksimumnya adalah sebesar $0,75 \%$, rata-rata sebesar $0,67 \%$ dengan standar deviasi sebesar 0,03. Dalam hal ini menunjukkan bahwa nilai rata-rata (mean) lebih besar daripada standar deviasi maka dapat dikatakan kualitas data cukup baik.

3. Jumlah pengamatan untuk variabel kualitas laba adalah sebesar 72 pengamatan yang diperoleh dari 27 perusahaan dengan periode 4 tahun diketahui memiliki nilai minimum sebesar 0,04 dimiliki oleh PT Pakuwon Jati Tbk pada tahun 2016, nilai maksimum sebesar 1,25 dimiliki oleh Perdana Gapuraprima Tbk. Dalam pada tahun 2014. Dari tabel 4.2 juga dapat dilihat nilai rata-rata sebesar 0,44 dengan standar deviasinya sebesar 0,26. Dalam hal ini menunjukkan bahwa nilai rata-rata (mean) lebih besar daripada standar deviasi maka dapat dikatakan kualitas data cukup baik.

\section{Uji Asumsi Klasik}

Tabel 4.2

Hasil Uji Normalitas

One-Sample Kolmogorov-Smirnov Test

\begin{tabular}{llr}
\hline & & $\begin{array}{c}\text { Unstandardized } \\
\text { Residual }\end{array}$ \\
\hline \hline $\mathrm{N}$ & & 72 \\
Normal Parameters & a,b & 0.000 \\
& Mean & 0.247 \\
Most Extreme & Std. Deviation & 0.103 \\
Differences & Absolute & 0.103 \\
& Positive & $0.083)$ \\
Test Statistic & Negative & 0.103 \\
Asymp. Sig. (2-tailed) & & $.058 \mathrm{c}$ \\
\hline
\end{tabular}

* Corresponding author's e-mail: holienroe@yahoo.co.id

http://openjournal.unpam.ac.id/index.php/JIA 
Jurnal Ilmiah Akuntansi Universitas Pamulang - Vol. 7, No. 2, Juli 2019 - Oktapiani \& Ruhiyat
a. Test distribution is Normal.
b. Calculated from data.
c. Lilliefors Significance Correction.

Sumber : Output IBM SPSS Statistics 22.0 (diolah 2019)

Nilai Asymp. sig. (2-tailed) adalah sebesar 0,058 dimana memiliki nilai yang lebih besar dari tingkat kekeliruan sebesar 5\% atau 0,05 , hal ini berarti model regresi berdistribusi normal sehingga uji normalitas terpenuhi.

Untuk lebih menyakinkan normalitas data maka diuji juga dengan melihat grafik probability plot (P-Plot) sebagai berikut :

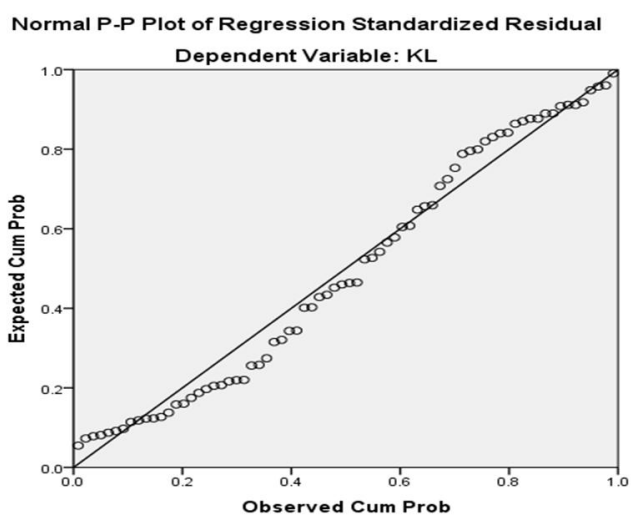

Gambar 4.1

Hasil Uji Normalitas

Titik-titik tidak menjauh dari garis diagonal (Gambar 4.1) yang berarti model regresi berdistribusi normal sehingga uji normalitas terpenuhi.

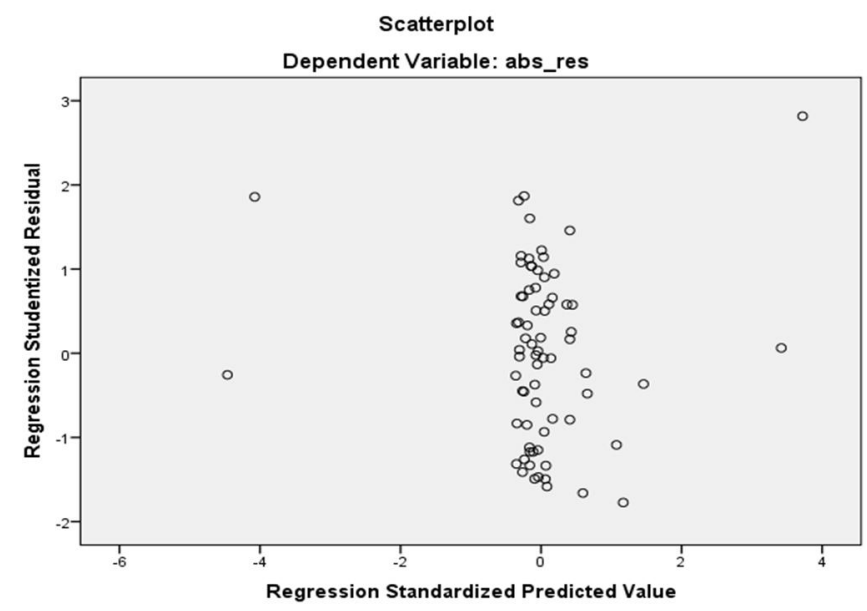

Gambar 4.2

Hasil Uji Heteroskedastisitas 
Jurnal Ilmiah Akuntansi Universitas Pamulang - Vol. 7, No. 2, Juli 2019 - Oktapiani \& Ruhiyat

Grafik scatterplot terlihat bahwa titik-titik menyebar secara acak dan menyebar di bawah dan di atas angka nol, sehingga dapat disimpulkan tidak terjadi heteroskedastisitas dan model regresi dapat digunakan untuk pengujian berikutnya. (Gambar 4.2).

\section{Tabel 4.3}

Hasil Uji Multikolinearitas

\begin{tabular}{|c|c|c|c|}
\hline & & \multicolumn{2}{|c|}{ Collinearity Statistics } \\
\hline & & Tolerance & VIF \\
\hline \multirow{3}{*}{1} & (Constant) & & \\
\hline & IOS & 0.901 & 1.109 \\
\hline & Komite Audit & 0.901 & 1.109 \\
\hline \multicolumn{4}{|c|}{ a. Dependent Variable: KL } \\
\hline
\end{tabular}

Untuk mengetahui ada tidaknya multikolinieritas data dapat dilihat dari nilai VIF. Pada tabel 3 nilai tolerance dan VIF terlihat bahwa tidak ada nilai tolerance di bawah 0.10 (nilai tolerance berkisar 0.901), begitu juga dengan VIF tidak ada yang di atas 10 (nilai VIFberkisar antara 1.109) sehingga dapat disimpulkan tidak ada indikasi terjadi multikolinearitas antar variabel independen penelitian dan model regresi dapat digunakan untuk pengujian berikutnya.

Tabel 4.4

\section{Hasil Uji Autokolerasi}

\begin{tabular}{|c|c|c|c|c|c|}
\hline Model & $\mathbf{R}$ & R Square & $\begin{array}{c}\text { Adjusted R } \\
\text { Square }\end{array}$ & $\begin{array}{l}\text { Std. Error of } \\
\text { the Estimate }\end{array}$ & $\begin{array}{l}\text { Durbin- } \\
\text { Watson }\end{array}$ \\
\hline 1 & $.349 \mathrm{a}$ & 0.122 & 0.096 & 0.250 & 1.928 \\
\hline \multicolumn{6}{|c|}{ a. Predictors: (Constant), KAT, IOS } \\
\hline \multicolumn{6}{|c|}{ b. Dependent Variable: KL } \\
\hline \multicolumn{6}{|c|}{ Sumber : Output IBM SPSS Statistics 22.0 (diolah 2019) } \\
\hline
\end{tabular}

Untuk mengetahui ada tidaknya autokorelasi dapat dilihat dari nilai DW (durbin Watson). Pada tabel 4.4 terlihat hasil nilai DW sebesar 1,928, dan selanjutnya dilakukan uji hasil DW dengan tabel DW, sebagi berikut :

* Corresponding author's e-mail: holienroe@yahoo.co.id 
Jurnal Ilmiah Akuntansi Universitas Pamulang - Vol. 7, No. 2, Juli 2019 - Oktapiani \& Ruhiyat

Tabel 4.5

Hasil Uji Autokolerasi

\begin{tabular}{ccccc}
\hline $\mathrm{d}$ & $\mathrm{dl}$ & $\mathrm{du}$ & $4-\mathrm{dl}$ & $4-\mathrm{du}$ \\
\hline 1.928 & 1.5323 & 1.7054 & 2.4677 & 2.2946 \\
\hline
\end{tabular}

Berdasarkan tabel 5 nilai DW 1.928 lebih besar dari batas bawah (du) 1.7054 dan lebih kecil dari batas atas (4-du) 2.2946 yang berarti berada pada daerah yang tidak ada autokolerasi positif atau negatif.

\section{Uji Hipotesis}

Uji Model Regresi Linear Berganda dan Signifikasi Simultan (Uji Statistik F)

Uji ini dilakukan untuk menguji apakah variabel-variabel independen terhadap variabel dependen memiliki pengaruh secara bersama-sama. Pengujian dilakukan dengan menggunakan tingkat signifikansi 0,05 ( $\alpha=5 \%)$.

Tabel 4.6

Uji Signifikasi Simultan (Uji Statistik F)

\begin{tabular}{llccccc}
\hline Model & $\begin{array}{c}\text { Sum of } \\
\text { Squares }\end{array}$ & Df & $\begin{array}{c}\text { Mean } \\
\text { Square }\end{array}$ & F & Sig. \\
\hline \hline Regression & 0.601 & 2.000 & 0.300 & 4.789 & $.011 \mathrm{~b}$ \\
1 & Residual & 4.329 & 69.000 & 0.063 & & \\
Total & 4.930 & 71.000 & & & \\
\hline
\end{tabular}

a. Dependent Variable: KL

b. Predictors: (Constant), KAT, IOS

Sumber : Output IBM SPSS Statistics 22.0 (diolah 2019)

Berdasarkan table 4.9 uji ANOVA atau $\mathrm{F}$ test diperoleh $\mathrm{F}$ hitung sebesar 4,789 dengan nilai signifikan (sig) sebesar 0,011. Berdasarkan hasil tersebut dapat disimpulkan:

1. Model regresi linear berganda terbukti valid untuk selanjutnya dapat dilanjutkan menguji hipotesis penelitian ini.

2. Hasil ini juga memberi bukti empiris bahwa secara simultan IOS dan komite audit berpengaruh signifikan terhadap kualitas laba dan dengan demikian hipotesi satu (H1) gagal ditolak. 
Jurnal Ilmiah Akuntansi Universitas Pamulang - Vol. 7, No. 2, Juli 2019 - Oktapiani \& Ruhiyat

Analisis Regresi Linear Berganda

Tabel 4.7

Hasil Analisis Regresi Linier Berganda

\begin{tabular}{|c|c|c|c|}
\hline \multirow{2}{*}{ Model } & \multicolumn{2}{|c|}{ Unstandardized Coefficients } & \multirow{2}{*}{$\begin{array}{c}\begin{array}{c}\text { Standardized } \\
\text { Coefficients }\end{array} \\
\text { Beta }\end{array}$} \\
\hline & B & Std. Error & \\
\hline 1 (Constant) & 2.430 & 0.656 & \\
\hline IOS & .005 & .023 & .026 \\
\hline KAT & -2.987 & 0.996 & -.356 \\
\hline
\end{tabular}

a. Dependent Variable: KL

Sumber : Output IBM SPSS Statistics 22.0 (diolah 2019)

Dari tabel 9 dapat disusun persamaan regresi. Persamaan regresi linear berganda pada penelitian ini sebagai berikut :

Kualitas Laba $=2.430+0.05$ IOS- 2.987 Kualitas Audit

Pada persamaan regresi di atas menunjukkan nilai konstanta yaitu sebesar 2,430 . Hal ini menyatakan bahwa jika variabel investment opportunity set (X1) dan komite audit (X2) dianggap konstan (nol), maka kualitas laba (Y) sebesar 2,430 .

Koefisien regresi pada variabel investment opportunity set sebesar 0,005 menunjukkan bahwa setiap kenaikan investment opportunity set maka kualitas laba perusahaan mengalami kenaikan dengan asumsi variabel komite audit konstan.

Koefisien regresi pada variabel komite audit sebesar -2,987 menunjukkan bahwa setiap penurunan kinerja komite audit maka kualitas laba perusahaan mengalami penurunan dengan asumsi variabel investment opportunity set konstan.

Tabel 4.8

Hasil Uji Koefisien Determinasi $\left(\mathbf{R}^{2}\right)$

\begin{tabular}{ccccc}
\hline Model & R & R Square & $\begin{array}{c}\text { Adjusted R } \\
\text { Square }\end{array}$ & $\begin{array}{c}\text { Std. Error of } \\
\text { the Estimate }\end{array}$ \\
\hline \hline 1 & $.349 \mathrm{a}$ & 0.122 & 0.096 & 0.250 \\
\hline
\end{tabular}

a. Predictors: (Constant), KAT, IOS

b. Dependent Variable: KL

Sumber : Output IBM SPSS Statistics 22.0 (diolah 2019)

Tabel 10 menunjukkan bahwa nilai adjusted R-Square sebesar 0,096. Berarti bahwa variabel kualitas laba dapat dipengaruhi oleh investment opportunity 
Jurnal Ilmiah Akuntansi Universitas Pamulang - Vol. 7, No. 2, Juli 2019 - Oktapiani \& Ruhiyat

set dan komite audit sebesar 9,6\%. Sedangkan 90,4\% dipengaruhi oleh faktorfaktor lain di luar penelitian ini.

Tabel 4.9

Uji Signifikansi Parsial (Uji Statistik t)

\begin{tabular}{|c|c|c|c|c|c|c|}
\hline & \multirow{2}{*}{ Model } & \multicolumn{2}{|c|}{$\begin{array}{c}\text { Unstandardized } \\
\text { Coefficients }\end{array}$} & \multirow{2}{*}{$\begin{array}{c}\begin{array}{c}\text { Standardized } \\
\text { Coefficients }\end{array} \\
\text { Beta } \\
\end{array}$} & \multirow{2}{*}{$\mathbf{t}$} & \multirow{2}{*}{ Sig. } \\
\hline & & B & Std. Error & & & \\
\hline \multirow[t]{3}{*}{1} & (Constant) & 2.430 & 0.656 & & 3.704 & .000 \\
\hline & IOS & .005 & .023 & .026 & 0.216 & .829 \\
\hline & KAT & -2.987 & 0.996 & -.356 & -2.999 & .004 \\
\hline
\end{tabular}

Sumber : Output IBM SPSS Statistics 22.0 (diolah 2019)

Hasil Uji Signifikasi Parsial (Uji Statistik t) pada tabel 11 sebagai berikut :

1. Variabel investment opportunity set memilliki nilai t-hitung sebesar $0,216<$ t-tabel (2-tiled) 1,9949. Demikian juga hasil signifikan menunjukkan nilai $0,829>0,05$. Maka H2 ditolak artinya investment opportunity set tidak berpengaruh terhadap kualitas laba.

2. Variabel komite audit memilliki nilai t-hitung sebesar 2,999 > t-tabel (2tiled) 1,9949. Demikian juga hasil signifikan menunjukkan nilai $0,004<$ 0,05. Maka H3 gagal ditolak artinya komite audit berpengaruh positif terhadap kualitas laba.

\section{Diskusi Hasil dan Pembahasan}

\section{Pengaruh Investment Opportunity Set dan Komite Audit terhadap Kualitas Laba}

Berdasarkan table 4.9 uji ANOVA atau $\mathrm{F}$ test diperoleh $\mathrm{F}$ hitung sebesar 4,789 dengan nilai signifikan (sig) sebesar 0,011. Oleh karena nilai signifikansi lebih kecil dari 0.05 , maka $\mathrm{H} 1$ yang menyatakan bahwa diduga investment oppportunity set dan komite audit berpengaruh positif terhadap kualitas laba dapat disimpukan gagal ditolak. Sehingga secara simultan investment opportunity set dan komite audit berpengaruh terhadap kualitas laba.

Hasil ini menunjukkan bahwa bila manajemen berkeinginan meningkatkan kualitas laba maka tingkatkan IOS dan pada saat bersamaan tingkatkan kinerja komite audit. Bila kedua faktor tersebut ditingkatkan secara bersamaan maka kualitas laba akan lebih baik.

2. Pengaruh Investment Opportunity Set terhadap Kualitas Laba

Berdasarkan hasil uji stastistik $\mathrm{t}$ yang terlihat di tabel 11, investment opportunity set yang diproksikan dengan MBVE (Market to Book Value of Equity) terlihat bahwa IOS memiliki nilai signifikansi 0,829 (82,9\%) atau berada diatas nilai signifikansi $0,05(5 \%)$. Hasil tersebut menunjukkan bahwa IOS tidak berpengaruh signifikan terhadap kualitas laba pada perusahaan property dan real estate yang terdaftar di BEI periode 2014- 
Jurnal Ilmiah Akuntansi Universitas Pamulang - Vol. 7, No. 2, Juli 2019 - Oktapiani \& Ruhiyat

2017. Hasil tidak berpengaruhnya IOS terhadap kualitas laba berbeda dengan teori sinyal yang mengemukakan bahwa dengan perusahaan mengumumkan informasi dapat memancing reaksi pasar. Informasi merupakan sinyal positif, apabila informasi tersebut memberikan dampak positif.

Hasil penelitian ini tidak sejalan dengan hasil penelitian yang dilakukan oleh Wijaya (2014) dan Prasetyawati (2015) yang menyimpulkan bahwa investment opportunity set berpengaruh terhadap kualitas laba. Kedua peneliti tersebut melakukan penelitian pada perusahaan Manufaktur yang terdaftar di Bursa Efek Indonesia.

Hasil penelitian ini sejalan dengan Kurniawan (2016) yang menyimpulkan hasil bahwa investment opportunity set tidak berpengaruh terhadap kualitas laba dengan nilai signifikannya $0,128>0,050$. Tidak berpengaruhnya IOS terhadap kualitas laba dikarenakan motivasi investor dalam investasinya bukan untuk mendapatkan keuntungan jangka panjang, melainkan untuk mendapatkan capital gain (jangka pendek). Faktor kesempatan bertumbuh yang dilihat dari investment opportunity set biasanya diamati oleh investor yang mempunyai perspektif jangka panjang untuk mendapatkan tingkat bunga (yield) dari investasi yang dilakukannya.

Pengaruh investment opportunity set yang tidak signifikan terhadap kualitas laba dikarenakan investment opportunity set tidak menjadi pusat perhatian investor dalam membuat keputusan investasi. Sehingga investor tidak terlalu memerhatikan nilai investment opportunity set perusahaan, namun lebih memerhatikan angka laba perusahaan.

\section{Pengaruh Komite Audit terhadap kualitas laba}

Tabel 11 menunjukkan hasil uji stastistik komite audit yang diukur dengan persentase jumlah anggota komite audit yang berasal dari luar perusahaan dengan jumlah keseluruhan angggota komite audit terlihat bahwa komite audit yang memiliki nilai signifikansi $0,004(0,4 \%)$ atau berada dibawah nilai signifikansi 0,05 (5\%). Hasil tersebut menunjukkan bahwa komite audit berpengaruh terhadap kualitas laba pada perusahaan property dan real estate yang terdaftar di BEI periode 2014-2017.

Hasil penelitian ini sejalan dengan hasil Suryana (2005) yang menyimpulkan hasil bahwa komite audit berpengaruh positif terhadap kualitas laba. Hasil penelitian ini menunjukkan bahwa koefisien respons laba perusahaan yang membentuk komite audit secara statistik lebih besar dari laba yang dilaporan oleh perusahaan yang tidak memiliki komite audit.

Beberapa penelitian telah menguji hubungan antara komte audit dan kualitas laba. Anderson et al. (2003) menemukan bahwa karakter komite audit (independensi, aktivitas dan komite audit) memengaruhi kandungan informasi laba yang diukur dengan ERC. Peningkatan independensi dan aktivitas komite audit berpengaruh positif terhadap kandungan informasi dari laba. Pengaruh peningkatan independensi komite semakin berkurang pada saat komite audit aktif. Bryan et al. (2004) menemukan bahwa ERC lebih kuat ketika anggota komite audit independen dan ahli dalam bidang keuangan. 
Jurnal Ilmiah Akuntansi Universitas Pamulang - Vol. 7, No. 2, Juli 2019 - Oktapiani \& Ruhiyat

\section{KESIMPULAN}

1. Secara simultan investment opportunity set (IOS) dan komite audit terbukti secara empiris berpengaruh signifikan terhadap kualitas laba.

2. Investment opportunity set (IOS) tidak terbukti secara empiris berpengaruh signifikan terhadap kualitas laba.

3. Komite audit terbukti secara empiris berpengaruh signifikan terhadap kualitas laba.

\section{Implikasi Penelitian}

Untuk meningkatkan kualitas laba perusahaan, manajemen harus berupaya mendorong para investor untuk tidak hanya memerhatikan laba jangka pendek tapi juga jangka panjang dan terus meningkatkan kinerja komite audit

\section{Keterbatasan Penelitian}

Akibat kesulitan memperoleh data sehingga penelitian ini tidak melakukan uji sensitivitas.

\section{Saran}

Penelitian selanjutnya diharapkan dapat mengembangkan faktor konservatisme akuntansi sebagai variabel pemoderasi sehingga dengan demikian kita dapat melihat apakah konservatisme akuntansi dapat memperkuat pengaruh IOS terhadap kualitas laba. Selain itu tambahkan juga faktor-faktor pengendali (control variabel) agar hasil penelitiannya lebih robust.

\section{DAFTAR PUSTAKA}

Anderson , K.L., Deli., D.N.., dan Gillan, S.T. (2003). "Board of Directors, Audit Committees, and the Information Content of Earnings : Working Papers September.

Bradbury,et al. (2004). Board Characteristics, Audit Committee Characteristics, and Abnormal Accruals.Working Paper. United New Zealand dan National University of Singapore. Unduh 22-092019

Bryan, D., Liu, M. H. C., dan Tiras, S. L. (2004). "The Influence of Independent and Effective Audit Committees on Earnings Quality". Working paper. Januari 2004.

Kurniawan, A. (2016). Pengaruh Struktur Modal, Likuiditas, Investment Opportunity Set (IOS), Pertumbuhan Laba, Persistensi Laba dan Ukuran Perusahaan Terhadap Kualitas laba. Jurnal Akuntansi Universitas Muhammadiyah Yogyakarta.

Lestari Setianingsih. (2016). Pengaruh Investement Opportunity Set, Likuiditas dan Good Corporate Governance Terhadap Kualitas Laba Pada 
Jurnal Ilmiah Akuntansi Universitas Pamulang - Vol. 7, No. 2, Juli 2019 - Oktapiani \& Ruhiyat

Perusahaan (Studi Empiris Pada Perusahaan Manufaktur Yang Terdaftar di BEI Periode 2010-2013). Jurnal Ilmiah Mahasiswa S1 Akuntansi Universitas Pandanaran ISSN : 2502-7697 Vol. 2 No. 2. (2016).

Michael Spence. (1973). Job Market SignalingAuthor(s): The Quarterly Journal of Economics, Vol. 87, No. 3 (Aug., 1973), pp. 355-374Published by: The MIT PressStable URL: http://www.jstor.org/stable/1882010 unduh 22-09-2019

Michael C. Jensen and William H. Meckling. (1976). Theory of The Firm: Managerial Behavior, Agency Costs and Ownership Structure * University of Rochester, Rochester, NY 14627, U.S.A. Journal of Financial Economics 3 (1976) 305-360. Q North-Holland Publishing Company

Nurhanifah, YA., \& Jaya T., E. (2014). Pengaruh Alokasi Pajak Antar Periode, Investment Opportunity Set dan Likuiditas terhadap Kualitas Laba. Jurnal Ilmiah Wahana Akuntansi.

Nurhanifah, YA., \& Jaya T., E. (2014). Pengaruh Alokasi Pajak Antar Periode, Investment Opportunity Set dan Likuiditas terhadap Kualitas Laba. Jurnal Ilmiah Wahana Akuntansi.

Oktarya, E., Syafitri, L., \& Wijaya T. (2014). Pengaruh Pertumbuhan Laba, Investment Opportunity Set, Leverage dan Ukuran Perusahaan Terhadap Kualitas Laba. Eprints MDP Business School.

Otoritas Jasa Keuangan Republik Indonesia. (2015). Peraturan Otoritas Jasa Keuangan Nomor 55/POJK.04/2015 tentang Pembentukan dan Pedoman Pelaksaan Kerja Komite Audit.

Prasetyawati, D., K. (2015). Pengaruh Konservatisme dan Investment Opportunity Set Terhadap Kualitas Laba. Jurnal Akuntansi UNESA.

Reyhan, A., \& Azlina, N. (2014). Pengaruh Komite Audit, Asimetri Informasi, Ukuran Perusahaan, Pertumbuhan Laba Dan Profitabilitas Terhadap Kualitas Laba. Jurnal Online Mahasiswa Ekonomi Universitas Riau.

Silvi, A. (2016). Pengaruh Pertumbuhan Laba, Struktur Modal, Likuiditas dan Komite Audit Terhadap Kualitas Laba. Jurnal Valuta Vol 2 No 1.

Stewart C. Myers. (1983). The Capital Structure Puzzle. The Journal of Finance, Vol. 39, No. 3, Papers and Proceedings, Forty-Second Annual Meeting, American Finance Association, San Francisco, CA, December 28-30, 1983. (Jul., 1984), pp. 575-592.

Suryanto, T. (2016). Pengaruh Accounting Disclosure, Accounting Harmonization dan Komite Audit terhadap kualitas laba. Jurnal Akuntansi/Volume XX.

Warianto, P., \& Rusiti Ch. (2014). Pengaruh Ukuran Perusahaan, Struktur Modal, Likuiditas, dan Investment Oppoertunity Set Terhadap Kualitas Laba. Jurnal Modus Vol. 26. 